Trinity University

Digital Commons @ Trinity

Philosophy Faculty Research

Philosophy Department

Winter 2005

\title{
Against the Ubiquity of Fictional Narrators
}

Andrew Kania

Trinity University, akania@trinity.edu

Follow this and additional works at: https://digitalcommons.trinity.edu/phil_faculty

Part of the Philosophy Commons

\section{Repository Citation}

Kania, A. (2005). Against the ubiquity of fictional narrators. The Journal of Aesthetics and Art Criticism, 63(1), 47-54. doi:10.1111/j.0021-8529.2005.00180.x

This Post-Print is brought to you for free and open access by the Philosophy Department at Digital Commons @ Trinity. It has been accepted for inclusion in Philosophy Faculty Research by an authorized administrator of Digital Commons@ Trinity. For more information, please contact jcostanz@trinity.edu. 


\section{Against the Ubiquity of Fictional Narrators}

Andrew Kania

[This is the peer reviewed version of the following article: Andrew Kania, “Against the Ubiquity of Fictional Narrators” Journal of Aesthetics and Art Criticism 63 (2005): 47-54, which has been published in final form at http://onlinelibrary.wiley.com/doi/10.1111/j.0021-8529.2005.00180.x/abstract.

This article may be used for non-commercial purposes in accordance with Wiley Terms and Conditions for Self-Archiving. Please cite only the published version.]

\section{Abstract}

In this paper I argue against the theory - popular among theorists of narrative artworks that we must posit a fictional narrative agent in every narrative artwork in order to explain our imaginative engagement with such works. I accept that every narrative must have a narrator, but I argue that in some central literary cases the narrator is not a fictional agent, but rather the actual author of the work. My criticisms focus on the strongest argument for the ubiquity of fictional narrators, Jerrold Levinson's ontologicalgap argument. Finally, I outline an alternative "minimal theory" of narrators, and some consequences thereof. 


\section{Against the Ubiquity of Fictional Narrators}

A large group of artworks can be usefully classified as narratives. These are works that tell stories. It is a far from easy task to set down criteria for membership in this genus, and I shall not be attempting that here. ${ }^{1}$ Rather, taking the genus of narrative artworks for granted, I will investigate one species: narrative literature. A number of recent theorists most notably Seymour Chatman, Jerrold Levinson, and George Wilson - have argued that there is necessarily a fictional narrator in every narrative, a conclusion I call the “ubiquity thesis.” I shall argue that the ubiquity thesis is mistaken, since certain paradigmatic novels and stories have no narrator in the sense these theorists employ. ${ }^{2}$ Though I limit my discussion here to literary narratives, what I propose could be adapted for other species of narrative, a point I return to at the end of the paper.

\section{THE NATURE OF THE FICTIONAL NARRATOR}

Before we investigate whether or not novels invariably have narrators, we should establish the nature of the snark we are hunting. I shall be disputing the ubiquity of a narrator understood as possessing just two essential features. The first is agency. Chatman, Levinson, and Wilson all point out that narration is an activity, something that gets done, and as such implies an agent. But their strongest motivation behind specifying "agency" as a feature of narrators is that it is a broader term than "humanity." It is easy to point out that if novels have narrators, they often know more than, and have powers greater than, any human could. Thus, a ubiquity theorist must insist from the start that "human personality is not a sine qua non for narratorhood."3

The second distinguishing feature these narrators have is fictionality. That is, these theorists claim that each novel's narrator is on the same ontological level as its 
characters and events. Again, they are at pains to point out that the claim is not that the narrator is a character in the traditional sense (though this may be the case - for example, in most novels narrated in the first person), merely that it is not to be posited at the level of actuality, but rather at the fictional level. ${ }^{4}$

Let me also make clear that I do not deny the existence of fictional narrators. They most obviously exist in first-person narrated novels. Indeed, it may be that most novels have fictional narrators. But I will argue that a certain central kind of novel has no fictional narrator, and that the ubiquity thesis is thus false. My strategy will be to investigate the main arguments for the ubiquity of fictional narrators in novels. I make use of several observations that George Wilson makes in "Le Grand Imagier Steps Out"; oddly enough, Wilson is there a ubiquity theorist, yet I believe his criticisms point towards a more restricted role for fictional narrators, one which he is simply unwilling ultimately to accept.

\section{THE ANALYTIC ARGUMENT}

We have already touched on the first argument for the ubiquity of fictional narrators what I call the “Analytic Argument.” The authority to look to here is Chatman. He argues that every narrative is by definition narrated - that is, narratively presented and that narration, narrative presentation, entails an agent even when the agent bears no signs of human personality. Agency is marked etymologically by the -er/-or suffix attached to the verbs "present" or "narrate." The suffix means either "agent” or "instrument," and neither need be human....The notion of "non-narrated” narrative arises as a misguided effort to restrict “agency” to human beings, but the restriction will not hold. ${ }^{6}$ 
Wilson and Levinson both cite parts of this passage, ${ }^{7}$ and Levinson offers his own formulation: "[I]f narration means anything, it is the conveying or imparting of a story by means [i.e. media] that are distinct both from the story being conveyed and from that which is doing the conveying [i.e. the narrative agent]..."

I believe this argument is sound. The only way I can imagine attacking it would be to claim that narration is something like biological growth - an event or process, but not an action, therefore implying no agent. I find this suggestion untenable. Stories do not simply appear out of thin air; they do not occur naturally, independently of human agency, as the growth of trees does. ${ }^{9}$ Paisley Livingston has argued that it may be indeterminate whether or not any given narrative has a narrator. ${ }^{10}$ But I cannot countenance this either. It is a simple conceptual point that stories must be told in some way by some thing.

However, we should note that the conclusion of the Analytic Argument is fairly weak. All it says is that there is an agent who is responsible for the narrative. This is compatible with the view that there are no fictional narrators. For authors would seem to be prima facie candidates for the agents responsible for their narratives. They do things that result in the stories we read. So the ubiquity theorist needs more to establish even the existence of fictional narrators, let alone their ubiquity.

III. THE ONTOLOGICAL-GAP ARGUMENT

Jerrold Levinson has provided the strongest argument that in order to make sense of our engagement with fictions, in addition to the author we need to posit a narrator at the fictional level. Though Levinson focuses on narrative film, it is clear that he would 
extend his argument to narrative literature. The argument has two main stages, and is founded on questions about how it is we come to know what is fictional in a work.

The first is a positive stage - it seeks to establish something. Levinson argues that we can reasonably expect an answer to how it is we are being given information about the world of the fiction we are reading or viewing. And the obvious answer is that someone is presenting it to us:

Reason - albeit reason operating in service of the imaginative understanding of fiction - demands an answer to how it is that a world is being made visible to us, and that demand, it appears, is only satisfied by the assumption of an agency responsible for that. ${ }^{11}$

The notion of a presenter, whose main charge is the providing of perceptual access on the fictional world, is simply the best default assumption available for how we make sense of narrative fiction film. ${ }^{12}$

At first this may not seem to establish anything more than the Analytic Argument did. But, as these quotations make clear, the Ontological-Gap Argument goes beyond the Analytic Argument by restricting the class of narratives being discussed to fictional narratives. Hence, the real bite of this argument comes at the second stage.

The second stage is negative - it seeks to deny that an agent who gives us epistemic access to a fictional world can coherently be considered to occupy a different ontological level from that world. The basic idea is that if the narrative agent were outside the fictional world - at our ontological level, say - it could not coherently present us with the story events and characters as if they were real, that is, on its own ontological level. Hence the narrator must be fictional, and thus cannot be the author (or filmmaker). 
A narrator and the events narrated by the narrator must be on the same fictional plane, otherwise cognitive relations posited between narrator and events would not make sense....The implied filmmaker can't be in the position of directly affording us - as with a silent gesture of "behold!" - the vision and audition of something that is only fictional with respect to himself, namely, the characters and their circumstances; that remains the prerogative of the film's narrator or presenter, who is, in a fundamental sense..."one of them."13

There are problems with both stages of this argument, and I will address them in turn. IV. THE POSITIVE STAGE

George Wilson makes some telling observations about the coherence of the foundations of fictions which should give us pause when considering Levinson's claim that we can reasonably expect answers to questions about our epistemic access to fictional worlds. Wilson points out that there may be paradoxes or incoherencies at the very base of fictional works. For instance, a novel may represent itself as a copy of a diary that must have been destroyed in the story-culminating fire. ${ }^{14}$ More commonly, it is indeterminate whether the narrator is supposed to be thinking the words we are reading, speaking them aloud, or has written them down, and in any case, how we are supposed to have gotten hold of a transcription or copy. ${ }^{15}$ The nicest example is provided by David Hills: "The Adventures of Huckleberry Finn...represents itself as a carefully crafted 300 page memoir by its title character, a barely literate young man getting ready to set out for the territories because the prospect of any work that requires him to sit still terrifies him." ${ }^{16}$ In sum: 
[T] he reader imagines reading a transcription of the narrator's own utterances or inscriptions, but her imagination does not specify anything about what makes it possible for her to do this. Fictionally, it is indeterminate how the reader can be acquainted, as she is, with the product of the narrator's storytelling performance. ${ }^{17}$

Now, the point of marshalling these observations here is to repel Levinson's first sally. If reason does not demand an answer to how we come to see or know about the fictional world, then the one that Levinson provides - namely, that there is a fictional narrator - is simply otiose. Of course, that will not be a very powerful rejoinder if the second stage of Levinson's argument leads to a successful theory. If a theory explains something, we do not need any extra motivation to adopt it. I will get to the adequacy of the second stage soon, but there is yet another problem Wilson's points raise for the first stage.

Suppose reason did demand an answer to the question of how we have access to the fictional world. And suppose we answered: "By means of a fictional narrative agent." What leads Levinson to believe that reason will be satisfied with that? Surely there are further questions to be asked, such as what sort of agent this is, how it knows so much about the world, and how it imparts this information to us? It seems odd to suppose that reason could take this first step on to the slippery slope of fiction-foundational questions by asking how we come to know about the fictional world, and then get a satisfactory grip with such a tenuous answer - that there is some fictional narrative agent - thus managing to resist sliding any further. This problem is even more glaring in Chatman's exposition. Immediately after an extended argument that reason demands an explanation 
of how we are presented with this story, and that a fictional narrator is the only possibility, he goes on to say that “[h]ow the narrator came to 'know' the provided information seems a nonquestion.” 18 This is a curiously sudden loss of interest.

However, even if we grant Levinson the first stage of his argument, the second stage is untenable. I turn again to Wilson for my cue. He makes a simple but crucial distinction between actual telling and fictional telling. The End of the Road (1958) is John Barth’s second novel. It is a first-person narrative by the main character, Jacob Horner. We can thus distinguish between the actual telling of the fictional story, which John Barth engages in, and the fictional telling of the story engaged in by Horner. Wilson's observation is that each of these tellings, by the Analytic Argument, entails a teller. But he points out that only the fictional telling implies a fictional teller (just as a fictional shooting, say, implies only a fictional gunman). The actual telling of the story implies only an actual teller.

Now, it so happens that Horner is, in Gregory Currie’s terminology, ${ }^{19}$ a controlling narrator: it is fictional that he produces a text identical to the one we have before us. It also happens that The End of the Road is the most coherently founded fiction I know. ${ }^{20}$ The text implies that Horner has produced it as Scriptotherapy - a part of his ongoing treatment at the Remobilization Farm. Unlike so many well-founded fictions, this explains not only the existence of this text in the fictional world, but also its literary qualities. ${ }^{21}$ But neither of these points is essential. David Copperfield (1849-50, Wilson's example) is a first person narrative by the eponymous main character, but it seems unlikely that Copperfield is a controlling narrator, and hence the fiction is ill-founded (or at least indeterminately founded). But clearly there are still two tellings here: Dickens's 
actual telling of the fictional story and Copperfield's fictional telling of his life-story. There are plenty of problematic cases also. It is not clear that we can take the belatedly intrusive first-person narrator in John Fowles’s The French Lieutenant's Woman to be the actual John Fowles (as the narrator tries to imply, at least on one level), or whether he is rather another fictional entity.

However, I would argue that there are also clear cases where there is no fictional telling. Graham Greene often writes in a plain third-person omniscient narrative style. In The Heart of the Matter (1948) he tells the pathetically tragic tale of Scobie, and I see no reason to suppose that anyone else does. Of course, there are various embedded narrators in the novel - most of the characters tell stories about their lives, as in most novels - but there seems to be no reason to posit any overarching narrator other than Greene. ${ }^{22}$ The book as a whole, unlike David Copperfield or The End of the Road, is simply not fictionally narrated.

\section{THE NEGATIVE STAGE}

At this point Levinson might fairly point out that I can claim all I want, but a claim is not a response. The second stage of his argument was precisely meant to show that though at first glance it might seem that actual authors narrate their novels, this is incoherent, because they cannot make the assertions about the fictional world that are clearly being made. Someone at the beginning of The Heart of the Matter claims that "Wilson sat on the balcony of the Bedford Hotel with his bald pink knees thrust against the ironwork.”23 Graham Greene is clearly not asserting this; he of all people should know that neither Wilson nor the Bedford Hotel exists. Indeed, four pages earlier, he has told us explicitly that "[n]o character in this book is based on that of a living person." ${ }^{24}$ Anyone prepared 
to make the assertion about Wilson and the Bedford must be at the fictional level, and Graham Greene is simply not. The simplest hypothesis we can make is that there is a fictional narrator who offers us these facts about the fictional world.

There are two ways of responding to this second stage of the argument. First, one can emphasize the continuity of Greene-style fictions with other fictional narratives where we do not infer a fictional narrator. Traditionally, the oral storyteller is given as an example. To bring things a little closer to home, consider telling a joke. Here you begin to tell an audience about an American, an Australian, and a New Zealander; but only the most churlish listeners ask for more details about them, or how you know them, or why we should trust what you say. ${ }^{25}$ Anyone who knows about joke-telling knows that these people do not really exist, that one should merely imagine that the events related occurred. An improvised (third-person omniscient) bedtime story is even closer to the case of the Greene novel. Indeed, I cannot see any relevant difference in kind between the bedtime story transcribed and the Greene novel. We know that the novel is "just” a story; we know we are only supposed to imagine these events' having occurred, not to believe they actually did, let alone that Greene believes they did.

Of course, it is not just Graham Greene who writes in this 'transparent' style, but he is an ideal example. ${ }^{26}$ Other commonly suggested candidates for exemplars of the style are Ernest Hemingway, and nineteenth-century English novelists. I believe the latter are much less simple and unproblematic than they are usually taken to be. There are often surprising interjections in the first person by narrators of indeterminate ontological level, or incoherent attempts at founding the fiction. I shy away from Hemingway as my example because somehow his prose retains a forceful personal style despite his complete 
narratorial self-effacement. Though none of this shows that there are fictional narrators in all nineteenth-century fiction, or Hemingway's works, it militates against using those works as rhetorically persuasive paradigmatic examples. Greene seems the ideal transparent stylist.

There is a second way to criticize the second stage of the Ontological-Gap Argument. This is to point out that it has internal tensions that ultimately undermine it. The second stage is based on the idea that the artist cannot present the fictional world to us, because she does not stand in the right relation to it - the two are on different ontological levels. This problem is solved by positing an agent at the fictional level, who thereby does stand in the right epistemic relation to the fictional world. But it is not clear that this is a solution to the problem Levinson sets up. The problem is that we have a bunch of things at the level of the real world - the artist and the audience, for instance and a bunch of things at the ontological level of the fiction - the characters and events of the story - and there is no bridge from the latter to the former, no way for the fictional to be presented to the real. The proposed solution is to add one more entity to the fictional world: a narrator. But how does this help us? If we could not simply look and see the fictional world, how is one more fictional entity supposed to change that? Another way to see the problem is to ask: If we cannot understand how the artist can reach down and show us the fictional world, how is it that the fictional narrator can reach up and show it to us? In fact, if we must choose between these alternatives, surely it makes more sense to accept the former. Clearly fictions are in some sense part of our world - we really do interact with them - so we should be able to have some sort of access to them. But it is not clear that the real world is part of every fictional world - certainly not in the same 
way - so it is not obvious that a fictional entity could have any intentional relation to a real entity, as presentation, or telling, implies. Thus it makes more sense to suppose a real agent could show the fictional to us than to suppose a fictional agent could.

A ubiquity theorist might try to respond to this apparent inconsistency in a number of ways. She might suggest that the narrator just presents the fictional world in a certain way, but not to us. We just happen to be in the right place at the right time and see what it is presenting. Or perhaps the narrator presents it to other unspecified fictional entities, and we look over their shoulders, unbeknownst to them.

But apart from specific worries about these particular suggestions - such as the coherence of the idea of a presentation to no one, and the epicyclic multiplication of fictional entities - they miss the main point of the objection. Unless the narrator has some sort of ontological dual-citizenship in the real and fictional worlds, there is still an ontological gap between us and the fictional world. Now, one might ask what the problem with such a gap is. And, indeed, I don't have one. ${ }^{27}$ But this avenue is not open to the ubiquity-theorist. If the ontological gap between the real and fictional worlds is not a problem, this strategy can't get off the ground. For without a problem, there is no need to posit another entity - a fictional narrator - to explain our access to Greene-style fictions.

Jerrold Levinson has responded to my criticisms of the Ontological-Gap Argument. ${ }^{28}$ He claims as common ground between us that John Barth and Charles Dickens “wrote texts which, when imaginatively engaged with in the prescribed way, convey stories, and that fictionally Jacob Horner and David Copperfield are telling us their stories," but he denies that this licenses the conclusion that "Barth and Dickens are 
telling fictional stories." ${ }^{29}$ But if John Barth and Charles Dickens do not tell fictional stories, who does? On Levinson's view, no one ever tells fictional stories (that is, no actual person).

Levinson does restrict his view to straightforward "reported” fictional narratives, avoiding the special problems of postmodern and other "storytelling” fictions (see §VI, below), so there is a position in logical space where one would allow that (only) the postmodernists and their ilk tell fictional stories. But, again, note the oddity of this conclusion. Postmodernists are supposed to be notorious for having rejected storytelling wherever possible. I maintain that writing a text that, when imaginatively engaged with in the manner prescribed by our fictional practices, conveys a story, just is one way among many of telling a story.

\section{A MINIMAL THEORY AND SOME CONSEQUENCES ${ }^{30}$}

I have acknowledged that there are two ontological levels involved in our engagement with fiction, that we are on a different one from the characters and events of the fiction, and yet that we come to know about the fictional world. How can I claim there is no problem here? The answer is simply that though there are two ontological levels, there is no relevant ontological or epistemological gap. It seems to me that we learn about a fictional world from the person who invented it - the artist - through the medium of the artwork. Concerns about how we have access to fictional worlds seem to me closely analogous to the problems about how we have access to possible worlds that Kripke was at such pains to dissolve. ${ }^{31}$ A fictional world is not like a distant planet that we need some magical telescope to find out about. Its nature is just as stipulated as that of any possible 
world we might propose. ${ }^{32}$ It is stipulated by the artist through the work. So to learn about it, we engage with the work.

As Wilson points out, if there is a fictional narrator it is usually pretty obvious from the work. ${ }^{33}$ If the story is told in the first person, ostensibly by someone with a different name from the author's, and it is sold as a novel, we have many good reasons to suppose that within this fiction being told there is also a fictional telling by a fictional agent. Sometimes the signs are much more subtle, as in the popular example of Henry James’s “The Liar.” But sometimes we have simply no reason to suppose there is a fictional telling of the story we read or see. In The Heart of the Matter, Graham Greene spins a good yarn, but there is no reason to posit an overarching fictional telling within it or co-extensive with it.

One advantage of my theory is that it can deal with all literary fictions, although one has to look at each case individually. Of the ubiquity theorists, only Levinson points out that the theory may not be able to handle “storytelling narrators” in Walton's terminology - narrators who clearly signal the fictionality of the story they are presenting. ${ }^{34}$ The two examples Levinson gives are William Makepeace Thackeray’s Vanity Fair (1847-8) and John Fowles’s The French Lieutenant’s Woman (1969). My view is that Thackeray is indeed narrating Vanity Fair, just much less self-effacingly than a Graham Greene, while Fowles’s narrator-as-impresario is too tricky to allow us to identify him unproblematically with the author. ${ }^{35}$

But whether or not you agree with my individual interpretations, ultimately our decision about whether there is a fictional narrator will be part of our intentional explanation of any given artwork. ${ }^{36}$ Both Vanity Fair and The End of the Road have 
inconsistent chronologies. Yet we believe only the latter has an unreliable narrator, in the usual sinister sense. Why? Because part of any complete understanding of The End of the Road must take account of the deliberate concealment of the inconsistent time-structure; it cries out for explanation. But the temporal inconsistencies in Vanity Fair, while even greater, seem merely to be errors - a function of the book's serial production. Nothing of interest to an understanding of Vanity Fair comes from a close investigation of the confusion of its temporal structure. ${ }^{37}$ Similarly, whether we posit a fictional narrator in The Heart of the Matter or "The Liar" is a question of what it would buy us in terms of understanding these works. If I understand these works correctly, the supposition of a fictional narrator in The Heart of the Matter would get us no further than the intuitive understanding that Greene himself is telling the tale. On the other hand, the supposition of a fictional narrator in "The Liar" makes sense of its boss-eyed view of the action, and gives rise to further interesting critical questions.

We can also use this general point to criticize some other narratological theories. Gregory Currie, for instance, argues that we can eliminate external narrators, putting (implied) authors in their place. Now, it is not entirely clear what he means by an "external” narrator, but he is discussing cases of unreliability like James’s “The Liar.” Thus an external narrator seems to be the kind of narrator the ubiquity thesis posits - an agent at the fictional level, but not a character involved in the action. Currie claims we can do without these posits, explaining away this sort of unreliability as ironic narration by the implied author.

This seems a procrustean solution to me. Unreliable narrators do not usually seem ironic. They often seem sinister or treacherous in their underhand subversion of the role 
of the omniscient narrator. Moreover, there seems to be no good reason to do away with unreliable fictional narrators. Unless we have independent reason to suppose that all narratives are narrated in the same way, by the same type of agent, there is no need to get rid of all fictional narrators. Let us introduce them where we need them, but only where we need them.

At this point, a ubiquity theorist might criticize my minimal theory by pointing to a possible parallel between hypothetical intentionalism and the ubiquity thesis. Hypothetical intentionalists argue that we should keep the hypothetical and actual authors separate in our theory even when the author's actual intentions agree with an ideal hypothesis about them. Similarly, mightn’t one argue that we should always give both the actual and the fictional narrator a place in our theory, even though in some cases (for example Greene-style fictions and most films) there seems to be no difference between the authorial and fictional narration ${ }^{38}$

We should not. Hypothetical intentionalism is a theory about how we properly go about interpreting works of art. If it is the right theory, we can appeal to it in disputing the meanings of individual works, but whether it is the right theory is a meta-question. The question of whether there is an overarching narrator at the fictional level is rather a question of the content of a work of art - that is, it is an interpretive question. I see no prima facie reason why we should suppose there is a general answer to it for all narratives, any more than we should suppose all narratives have a particular timestructure. Of course, there may be secunda facie reasons, so to speak, but I have shown that those thus far suggested are unsound. 
I have argued, then, that the best account of our engagement with literary narratives does not entail our always positing a fictional narrator - an agency at the fictional level that is credited with presenting the fictional world to us. Of course, since these are stories, there must be someone telling them, but unless there is some particular reason for thinking otherwise, I see no problem with the intuitive view that the person telling the story is the one who made it up - the author.

I will end by mentioning two areas about which my minimal theory invites further thought. One is the extension of my theory to other forms of narrative art, particularly film. Due to the collaborative nature of film production, it is contentious whether there is a single actual 'author' who could be thought to 'tell the story' of the film. But it might be that the most important component of my theory is that an entity at the actual rather than the fictional level is responsible for the telling of some tales. This might be consistent with a view that implied, rather than actual authors are the narrators of certain works. Another area my minimal theory may have implications for is theory of interpretation. Some theorists argue that any consideration of the actual artist in engaging with a work is inappropriate. But such consideration may be unavoidable if artists are sometimes the narrators of their works. ${ }^{39}$ 


\section{Notes}

${ }^{1}$ For a helpful introduction to the problem, see Paisley Livingston, "Narrative,” in The Routledge Companion to Aesthetics, ed. Berys Gaut and Dominic Lopes (London: Routledge, 2001), pp. 275-84.

${ }^{2}$ I will make this sense explicit in the next section, but let me say here that by "narrator" simpliciter I mean to cover all the variants such as “show-er,” "teller," "presenter," and “perceptual enabler” introduced by various theorists in order not to prejudice the discussion in favor of the literary narrator.

${ }^{3}$ Seymour Chatman, Coming to Terms: The Rhetoric of Narrative in Fiction and Film (Ithaca, NY: Cornell University Press, 1990), p. 115. Both Wilson and Levinson quote an alternative formulation from the same page. See George M. Wilson, "Le Grand Imagier Steps Out: The Primitive Basis of Film Narration,” Philosophical Topics 25 (1997): 296, and Jerrold Levinson, “Film Music and Narrative Agency,” in Post-Theory: Reconstructing Film Studies, ed. David Bordwell and Noël Carroll (Madison: University of Wisconsin Press, 1996), p. 251.

${ }^{4}$ I shall use the third person neuter pronoun to refer to a narrator in this technical sense, as this seems to fit these theorists' “pure agency” view best.

${ }^{5}$ George M. Wilson, “Le Grand Imagier Steps Out: The Primitive Basis of Film Narration,” Philosophical Topics 25 (1997): 295-318. In his earlier work, Wilson was more circumspect about the existence of fictional narrators. See George M. Wilson, Narration in Light: Studies in Cinematic Point of View (Baltimore: Johns Hopkins University Press 1986), pp. 126-44. Thomas Wartenburg has suggested, in private communication, that Wilson is not a ubiquity theorist in "Le Grand Imagier.” Perhaps 
Wilson equivocates on the matter, as a result of accepting the Analytic Argument earlier in his paper but not considering its implications for the theory he develops later (the "Mediated Version of the Fictional Showing Hypothesis”). But I believe the most charitable coherent reading of the paper implicates him as a ubiquity theorist.

${ }^{6}$ Chatman, Coming to Terms, pp. 115-6.

${ }^{7}$ Wilson, “Le Grand Imagier,” pp. 296-7; Levinson, “Film Music and Narrative Agency,” pp. 251-3.

${ }^{8}$ Levinson, “Film Music and Narrative Agency,” p. 250.

${ }^{9} \mathrm{I}$ do not mean to beg the question of the humanity of narrative agency here. Even ubiquity theorists agree that human agency must be part of the theory somewhere (say, at the level of authorship).

${ }^{10}$ Paisley Livingston, “Narration, Narrators, and Fictional Presentations: A Minimalist Position,” American Society for Aesthetics, Eastern Division Meeting, Baltimore, MD (1999).

${ }^{11}$ Levinson, "Film Music and Narrative Agency,” p. 256. Here, and in the following quotations, we can substitute something like “epistemically accessible” for "visible,” and “epistemic access” for “perceptual access.”

12 Ibid., p. 252.

13 Ibid., pp. 252-3.

${ }^{14}$ Wilson, “Le Grand Imagier,” p. 309.

${ }^{15}$ Gregory Currie is too quick to suppose literature can be well-founded. He says that "[w]ith literature it is often natural to imagine that what one is reading is a true account of 
certain events witnessed or otherwise known about by someone, who then went to the trouble of setting it all down for us in writing....” (Gregory Currie, Image and Mind: Film, Philosophy and Cognitive Science (Cambridge: Cambridge University Press, 1995), p. 266). But it does not take long to come up with intractable questions, such as how someone got to know these things, why they write so well, why they give their account such a literary structure, etc.

${ }^{16}$ David Hills in correspondence with George Wilson, cited in Wilson, "Le Grand Imagier,” p. 317, n. 28.

${ }^{17}$ Wilson, “Le Grand Imagier,” p. 309.

${ }^{18}$ Chatman, Coming to Terms, p. 130.

${ }^{19}$ Currie, Image and Mind, pp. 265-8.

${ }^{20}$ In Wilson’s sense, discussed above.

${ }^{21}$ See John Barth, The Floating Opera and The End of the Road (New York: Doubleday, 1988 [originally published 1956 and 1958]), pp. 333 \& 427-8, and his LETTERS: a novel (New York: G. P. Putnam’s Sons, 1979), p. 339. Perhaps embarrassed by his prepostmodern virtuosity in founding this fiction, in his later novel, LETTERS (1979), Barth complicates things by putting (a version of) himself in the fictional world and writing to Horner, apologizing for the coincidences between the earlier novel and Horner's life. He describes to Horner how he might have simply found just such a manuscript. Horner is distinctly nonplussed, replying that he finds the new foundation "less convincing than the novel itself” (LETTERS, p. 279).

22 'Embedded narrator' is another of Currie’s terms. See Image and Mind, pp. 265-8. 
${ }^{23}$ Graham Greene, The Heart of the Matter (Harmondsworth: Penguin, 1978 [originally published 1948]), p. 11.

${ }^{24}$ Ibid., p. 7.

${ }^{25}$ If there isn’t a Monty Python sketch like this, there should be.

${ }^{26}$ As Deborah Knight was quick to remind me, Greene also excels at fictional firstperson narration.

${ }^{27}$ See the next section for my dissolution of this problem.

${ }^{28}$ Private communication.

${ }^{29}$ Ibid.

${ }^{30}$ I dub mine a “minimal theory” after Paisley Livingston’s “minimalist position,” outlined in "Narration, Narrators, and Fictional Presentations". I come to similar conclusions by a different route. The main differences between our positions are that Livingston argues (1) that some narratives may have no narrator at all, because (2) our acquiescence in the indeterminacy of the foundations of fictions could be extended to the question of whether there is a narrator; that is, the question is not necessarily an answerable or even appropriate one.

${ }^{31}$ Saul A. Kripke, Naming and Necessity (Cambridge, Mass.: Harvard University Press, 1972), pp. 42-50.

32 Perhaps more so, since fictional worlds are arguably subject to fewer constraints than possible worlds.

${ }^{33}$ Wilson, “Le Grand Imagier,” p. 300. 
${ }^{34}$ Levinson, “Film Music and Narrative Agency,” p. 279, n. 11; Kendall Walton, Mimesis as Make-Believe (Cambridge, MA: Harvard University Press, 1990), pp. 368-72.

${ }^{35}$ Clearly my views about these particular works are defeasible without weakening my general theory.

${ }^{36}$ For the importance of intentional explanations, see Gregory Currie, "Interpretation and Objectivity,” Mind 102 (1993): 413-28, and Image and Mind, chapter 8. Wilson applies similar considerations to film fictions in Narration in Light, pp. 142-3.

${ }^{37}$ Notice that Thackeray cannot be an unreliable narrator for the Kripkean reasons mentioned above. The actual author constitutes the fictional world by his narration; the fictional world of Vanity Fair had no existence, prior to Thackeray’s telling, against which his reliability could be judged.

${ }^{38}$ In his earlier work, Wilson seems to suggest this for literary fiction, while recommending a more cautious approach, something like my minimal theory, for film fictions. See Narration in Light, pp. 134, 136-7.

39 There is no space to consider these issues in any depth here, but I hope to address them in the future.

I would like to thank the following for useful discussion of this topic: Jerrold Levinson, Paisley Livingston, Robert Stecker, the editor and an anonymous referee of this journal, and the participants in the 2002 NEH Summer Institute: Art, Mind, and Cognitive Science. I presented a version of this paper at a session of the 2002 ASA Annual Meeting. I would like to thank my commentator at that session, Deborah Knight, and the 
audience. I would also like to thank the ASA and the Cosmos Club Foundation for grants enabling me to attend that meeting. 